\title{
Orange Agribusiness Development Strategy in Banyuwangi
}

\author{
Ardito Atmaka Aji \\ Politeknik Negeri Banyuwangi, Indonesia \\ Kurniawan Muhammad Nur \\ Politeknik Negeri Banyuwangi, Indonesia \\ Bagus Putu Yudhia Kurniawan \\ Politeknik Negeri Jember, Indonesia
}

\begin{abstract}
This research aims to determine the most appropriate strategy to develop orange agribusiness in Banyuwangi Regency. Banyuwangi Regency was a national orange agribusiness center (pilot project) that has been established by Ministry of Agriculture. This research uses a qualitative descriptive study. Data was collected by observation, interviews and documentation. The research location was Bangorejo Subdistrict, Banyuwangi Regency, as the highest orange producing center in Banyuwangi Regency. The informants selection uses purposive sampling technique. Head of Horticultural Division of Banyuwangi Agriculture Office become the key informant. Data analysis techniques are IFE and EFE Analysis, IE Matrix, SWOT Matrix and QSPM Matrix. The results showed that the affecting factors of oranges production in Banyuwangi Regency were (1) plant population, (2) number of productive plants, (3) soil quality, (4) experienced labor. The general strategy in this research was quadrant II (Grow and develop). Strategic priority to increase orange agribusiness commodities uses the S-O (Strenghts-Opportunities) strategy through increased production and quality of orange to meet market demand by utilizing the role of agricultural extension agents.
\end{abstract}

Keywords: Banyuwangi Regency, Development Strategy, Orange Agribusiness.

DOI: $10.7176 / \mathrm{JBAH} / 9-16-02$

Publication date: August $31^{\text {st }} 2019$

\section{INTRODUCTION}

The development of horticulture agribusiness subsector has strategic value to become part of agricultural sector development. The diversity of horticultural plants in Indonesia as a tropical country can open up great opportunities for agribusiness development by community (Praditya, 2014). One commodities in horticulture agribusiness subsector was Siam Citrus (Citrus nobilis). East Java is the province with largest production of Siamese citrus in Indonesia in 2015. The largest production of Siamese citrus in East Java Province originates from Banyuwangi Regency which was 205,685 tons (BPS, 2016).

The Ministry of Agriculture has designated Banyuwangi as the National Citrus Center Pilot Project. The characteristics of siam oranges in Banyuwangi region are famous for the sweet, soft and fresh fruit texture, and easily peeled skin. These interesting characteristics are not accompanied by optimal management of post-harvest Siamese oranges in Banyuwangi and are still relatively simple so that farmers must experience fluctuating prices that affect the income of Siamese orange farmers. Citrus farmers in Bangorejo sub-district generally sell oranges without post-harvest value-added process, such as sorting, grading, and packaging because farmers do not want the difficulties and costs of carrying out these activities are expensive according to Siamese farmers. This was evident from the total production and prices in 2016, as shown in Figure 1.

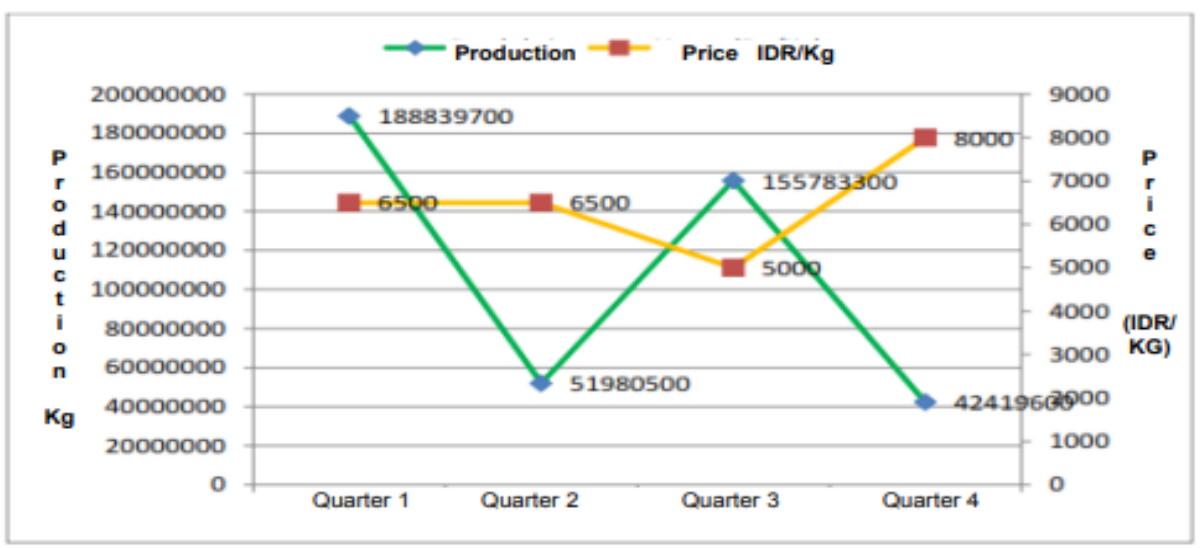

Figure 1 Production and price orange agribusiness 
Figure 1 shows that the high yield of Siamese fruit is shown in first quarter (January, February, March) and third quarter (July, August, September). The fluctuating price changes began to be felt in 3rd and 4th quarters. The prices at Quarter 3 declines 23\% than previous quarter caused by higher production at $199.7 \%$ than the previous quarter's production. The price at Quarter 4 jumped 60\% higher than Quarter 3 of IDR 8,000 caused by production of siam fruit which dropped drastically around $72 \%$ of total production in third quarter. Table 1 shows the price changes are caused by different amount of production at every quarter However, it can be seen in Q1 and 2 that prices did not change even though production in second quarter fell by $72 \%$. It shows the price is not only affected by production factor.

Some of previous studies became the reference for this study in relation to analysis of strategies to increase the orange agribusiness in Bangorejo District, Banyuwangi Regency, as red potato agribusiness development strategy (Fauzi, 2016). Can et. al. (2015) also found that SWOT analysis can be used to find the appropriate strategy in agriculture sector and Ghorbani et. Al (2015) shows that SWOT analysis can be used to improve the wetland usage in Iran. Michaildis et. al. (2015) also support the SWOT analysis for waste water treatment strategy for agriculture irrigation. Wan-Rong et. al. (2013) also show the benefit of SWOT Analysis in Development Strategies of Maize Industry in Heilongjiang Province and Rauch et. Al (2015) uses SWOT analysis for forest fuel supply chain. Shakerian et. al. (2016) uses SWOT hybrid to make human and business strategis and Arsic et. Al (2017) and Zhang (2012) used it in sustainable development of ecotourism. The marketing margin is used to increase the agriculture production through the difference between the prices paid by consumers and prices of producers themselves (Tesfaw et al, 2013), Kumar., Et al., (2017) conducted a research on Marketing Channels, Marketing Cost, Margin and Producer's Share in Consumer Rupees in Paddy Marketing. Etah District, Uttar Pradesh was chosen deliberately in study. Market channels are chosen for research namely, marketing channels, marketing costs, margins and producer shares. IE, SWOT, and QSPM analysis are analysis tools that can be used in this research.

The research formulation problem based on this background are: 1) how are internal and external factors affect the development of Siamese agribusiness in Banyuwangi? 2) how is the priority strategy to increase the effective orange citrus agribusiness in orange business in Banyuwangi to become a pilot project?

This study purpose was to analyze the strengths, weaknesses, opportunities and threats to improve the Siamese agribusiness in Bangorejo Subdistrict, Banyuwangi Regency: knowing the internal and external factors that influence the increase of Orange agribusiness, knowing the priority strategy to increase effective agribusiness in orange business in Bangorejo Subdistrict, Banyuwangi Regency as the center of national orange agribusiness (pilot project).

\section{RESEARCH METHODS}

The research location is Bangorejo District, Banyuwangi Regency, East Java Province. It uses primary and secondary data. Primary data is obtained from interviews with experts. The sampling technique used is purposive sampling based on respondents' expertise. Research respondents were 5 people consisting of: 1) Head of Banyuwang District Agriculture Service, 2) Chairperson of Bangorejo District Farmers Group Association, 3) educational academics from Banyuwangi State Polytechnic Campus, 4) Chairperson of Cendrawasih farmer group, 5) Chairperson of Menco farmer group. Secondary data is obtained from the Banyuwangi District agricultural service archives, literature books, as well as information tracing through the internet that could support research.

The research approach is a descriptive qualitative through a case study in Bangorejo District, Banyuwangi Regency. Data and information collection techniques are observation, interviews, and filling out questionnaires. Data analysis methods used include analysis of Internal Factor Evaluation (IFE), analysis of Externally Factor Evaluation (EFE), External Internal Matrix, Strengths, Weaknesses, Opportunities and Threats (SWOT) analysis, and strategy selection using Quantitative Strategic Planning Matrix (QSPM analysis) (David FR, 2010).

Descriptive analysis was used to explain vision and mission of development of Siamese agribusiness in Bangorejo District, Banyuwangi Regency. IFE and EFE are used to analyze internal and external factors to influence the development strategy of Orange agribusiness. IE matrix determines the position of Siamese orange farming in Bangorejo District. SWOT Analysis is used to formulate alternative strategies and QSPM analysis to get priority strategies. Bangorejo District, Banyuwangi Regency is one of orange agribusiness centers in East Java. The location of Banyuwangi Regency is feasible for development of Siamese agribusiness sector. Strategies for development of orange agribusiness are needed to ensure sustainable supply and improvement of products. The full research framework is shown in Figure 2. 


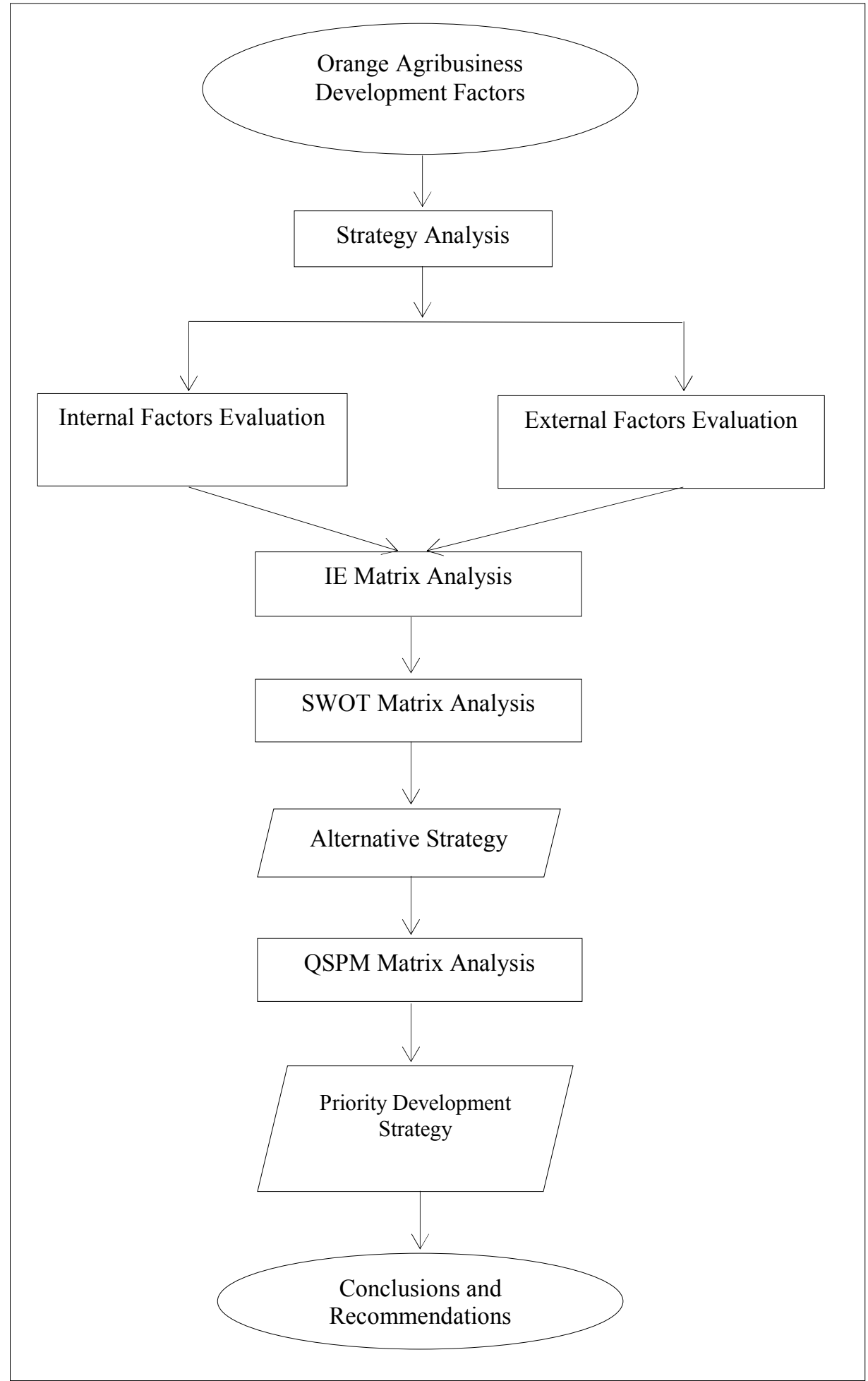

Figure 2 Research Thinking Framework Scheme

\section{RESULTS AND DICUSSION}

The interview results and questionnaire filling by respondents produce research data. It is used to show shows several factors of IFE and EFE analysis (strengths, weaknesses, opportunities, and threats), as shown below.

\section{Strengths}

The data analysis from interviews with expert speakers shows the strength of Siamese agribusiness in Bangorejo District, Banyuwangi Regency. They are plant populations, productive citrus plants, soil quality that support in cultivation, production farming facilities, agricultural irrigation and experienced farmers. 


\section{Weaknesses}

The internal factors show the weaknesses for development of orange agribusiness in Bangorejo District, Banyuwangi Regency. They are the lack of active farmer organization groups, lack of capital availability, lack of modern farming technology, not optimal product quality and lack of agricultural cooperatives.

\section{Opportunities}

Opportunities become factors that can be used as strategic factors in development of orange agribusiness in Bangorejo Subdistrict, Banyuwangi Regency. They are market demand, market share, consumer consumption interest, extension agents as facilitators and government policy support.

\section{Threats}

Threats become factors that can be used as strategic factors for development of orange agribusiness in Bangorejo Subdistrict, Banyuwangi Regency. They are the fluctuating protection of Siamese oranges, pest and disease attacks, rampant citrus imports, high conversion of agricultural land, climate change and weather. The results of IFE and EFE evaluation are presented in Table 1 and Table 2.

Table 1 Internal Factors Evaluation (Strengths and Weaknesses)

\begin{tabular}{|c|c|c|c|}
\hline Internal Factors Evaluation & Weight & Rating & Score \\
\hline \multicolumn{4}{|c|}{ Strengths } \\
\hline Plant population (1,784,375 plant) & 0.086 & 4 & 0.344 \\
\hline Productive orange plants $(1,338,375$ plant $)$ & 0.105 & 4 & 0.420 \\
\hline Soil quality supports in cultivation & 0.101 & 3 & 0.303 \\
\hline Production farming facilities & 0.083 & 4 & 0.332 \\
\hline Good agricultural irrigation (2 river streams) & 0.077 & 4 & 0.308 \\
\hline Farmers who are experienced in cultivation & 0.072 & 4 & 0.288 \\
\hline Total Strengths & & & 1.995 \\
\hline \multicolumn{4}{|c|}{ Weaknesses } \\
\hline Farmer organizations was less active & 0.092 & 2 & 0.184 \\
\hline Lack of capital availability & 0.103 & 1 & 0.103 \\
\hline Lack of modern farming technology & 0.096 & 2 & 0.192 \\
\hline Product quality is not optimal & 0.093 & 2 & 0.186 \\
\hline Do not have an agricultural cooperative & 0.092 & 2 & 0.184 \\
\hline Total Weaknesses & & & 0.849 \\
\hline Total Internal Factors Evaluation & 1 & & 2.844 \\
\hline
\end{tabular}

Tabel 2 External Factors Evaluation (Opportunities and Threats)

\begin{tabular}{|c|c|c|c|}
\hline External Factors Evaluation & Weight & Rating & Score \\
\hline \multicolumn{4}{|c|}{ Opportunities } \\
\hline Market demand & 0.125 & 4 & 0.500 \\
\hline Market share & 0.125 & 3 & 0.375 \\
\hline Consumers have high consumption interests & 0.098 & 4 & 0.392 \\
\hline Monitoring of extension workers as farming facilitators & 0.078 & 3 & 0.234 \\
\hline Government policy support & 0.092 & 3 & 0.276 \\
\hline Total Opportunities & & & 1.777 \\
\hline \multicolumn{4}{|c|}{ Threats } \\
\hline Price of fluctuating orange product & 0.100 & 3 & 0.300 \\
\hline Pests and diseases & 0.116 & 3 & 0.348 \\
\hline The rise of imported orange fruits & 0.085 & 2 & 0.170 \\
\hline The high conversion of agricultural land & 0.071 & 2 & 0.142 \\
\hline Climate change and weather & 0.111 & 3 & 0.333 \\
\hline Total Threats & & & 1.293 \\
\hline Total External Factors Evaluation & 1 & & 3.070 \\
\hline \multicolumn{4}{|c|}{$\begin{array}{l}\text { Bangorejo Subdistrict, Banyuwangi Regency is located quadrant II for the evaluation of internal and } \\
\text { external factors for the development of orange agribusiness. This is shown by IE matrix score }(2,816 ; 3,048) \text { to } \\
\text { put agribusiness in Bangorejo Subdistrict, Banyuwangi Regency in Grow and develop position. This position is a } \\
\text { condition to shows a high internal and external position. Therefore, the orange agribusiness in Bangorejo District, } \\
\text { Banyuwangi Regency improves the quality of production and post-harvest handling. The position of IE matrix is } \\
\text { shown in Figure } 3 \text {. }\end{array}$} \\
\hline
\end{tabular}


10.7176/JBAH

\section{Total value of IFE}

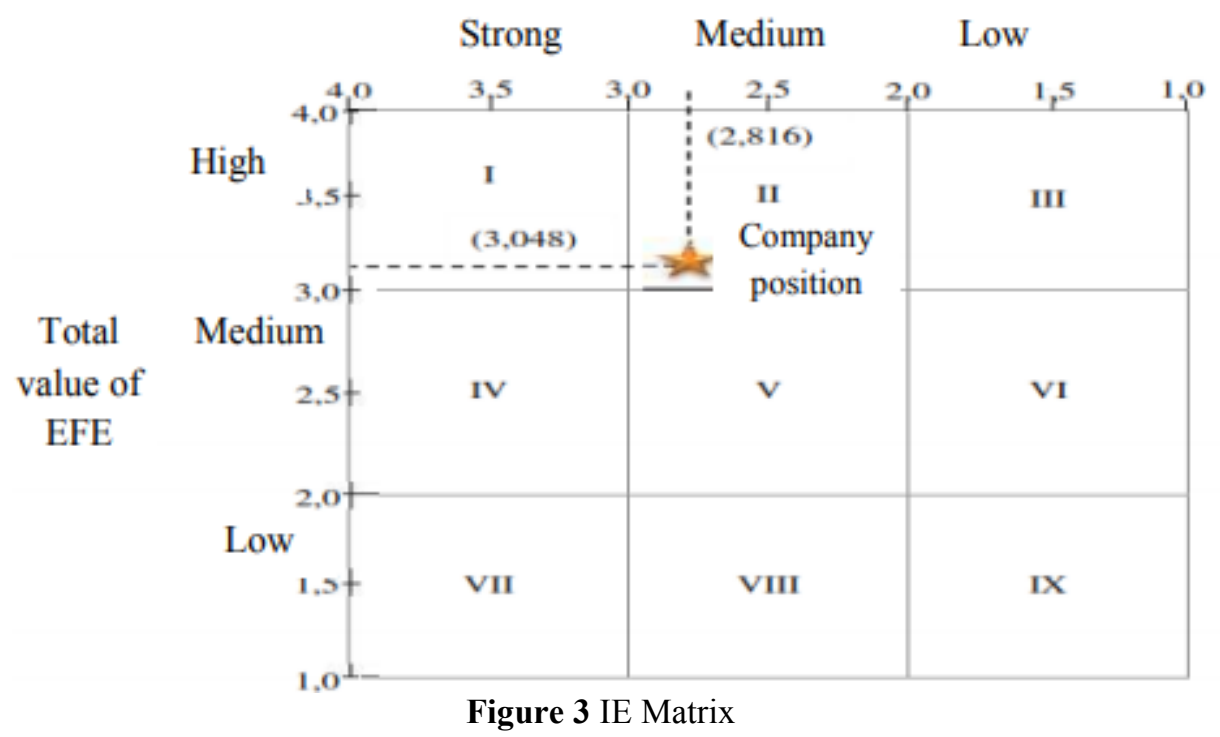

Figure 3 shows that the orange agribusiness in Bangorejo sub-district should uses an intensive strategy in form of market penetration strategies, market development and product development. SWOT Matrix analysis results shows 7 most appropriate strategies to develop orange agribusiness

The seven strategies are based on discussions and interviews with expert respondents. The reasons to choose the seven strategies are also strengthened based on considerations of product diversification, penetration and market and product development. The five choice strategies are then analyzed by QSPM matrix and the results are below.

The results of QSPM analysis show that the priority of choice of strategy is to implement a strategy to increase the production of orange to meet market demand by utilizing the role of agricultural extension agents. QSPM results can be seen in table 3 .

Tabel 3. Results of QSPM Matrix Analysis

\begin{tabular}{|c|c|c|c|}
\hline No & Alternative strategy & TAS & Priority \\
\hline 1 & $\begin{array}{l}\text { Increasing production and quality of siam oranges to meet market demand by utilizing } \\
\text { the role of agricultural extension agents }\end{array}$ & 6,062 & I \\
\hline 2 & Producing derivative products for the industrial raw materials & 5,565 & III \\
\hline 3 & Establishing an Agricultural Cooperative to increase capacity in capital and marketing & 5,386 & $\mathrm{~V}$ \\
\hline 4 & Improving the product competitiveness to be able to compete in free market & 5,667 & II \\
\hline 5 & $\begin{array}{l}\text { Increaseing the cooperation between providers of farming facilities, farmers and traders } \\
\text { Association }\end{array}$ & 5,511 & IV \\
\hline 6 & Improving the supervision of conversion of agricultural land & 5,160 & VII \\
\hline 7 & Improving the collaboration with Academics in product research and development & 5,259 & VI \\
\hline
\end{tabular}

Source: Primary Data Analysis, processed 2018

\section{Managerial and Policy Implications}

Agricultural intensification strategies must include farmer to implement Sapta farming. Sapta farming includes good soil processing, regular irrigation, selection of superior seeds, proper fertilization, integrated pest and disease control, efficient post-harvest handling and marketing. Therefore, they should follow education and training, counseling and mentoring, developing agricultural marketing systems and facilities, provision of financing and capital facilities, technology, and information and strengthening farmer institution

\section{CONCLUSIONS AND RECOMMENDATIONS}

\section{Conclusions}

Based on research results the conclusion are below.

1) The internal factors affecting the orange Agribusiness in Banyuwangi Regency based on Internal Factors are Citrus plant population, number of productive plants, soil quality, and experienced workforce. External factors affecting the orange Agribusiness in Banyuwangi Regency are industrial market demand, consumer consumption interest, government support to influence the development of orange agribusiness.

2) Priority strategy to increase the orange agribusiness commodities in Banyuwangi Regency is to use the S-O 
(Strengths-Opportunities) strategy through Increased Production and Quality of orange to meet market demand by utilizing the role of agricultural extension agents.

\section{Recommendations}

Recommendations are suggested to improve the implementation effectiveness of Siamese agribusiness development strategies in Banyuwangi Regency. Based on results of this study, researchers give below suggestions to several parties.

1) Orange Farmers in Banyuwangi

Farmers should further enhance collaboration with other farmers in form of an Agricultural Cooperative as a farmers group in Bangorejo sub-district. Farmers should carry out more intensive maintenance on siam orange to improve the quality and quality, in addition to need for compatibility in use of fertilizers and pesticides in production process to meet meet market demand. Farmers should pay attention to prices changes of production facilities and selling prices of siam oranges as a form of anticipation of uncertainty in future economic conditions.

2) Government

The government should pay more attention to the centers of orange production by facilitating farmers in form of latest technology information such as the use of seeds with superior varieties, connecting the relationship between farmers and banks, and optimizing the IPM SL program in farmer groups so the farmers can solve problems that often occur such as controlling high attack of plant pests.

\section{ACKNOWLEDGEMENT}

The author assures thanks to the Directorate General of Research and Development Strengthening (DRPM), Ministry of Research, and Technology and Higher Education for the assistance to this research.

\section{REFERENCES}

Amir Ghorbani, Valiollah Raufirad, Parisa Rafiaani, Hossein Azadi. 2015. Ecotourism sustainable development strategies using SWOT and QSPM model: A case study of Kaji Namakzar Wetland, South Khorasan Province, Iran. Tourism Management Perspectives, Volume 16, Pages 290-297

BPS | Badan Pusat Stastistik dan Departemen Pertanian. 2017. Laporan Tanaman Buah - Buahan dan Sayuran Tahunan. Banyuwangi, BPS dan DEPTAN

BPS | Badan Pusat Stastistik Kabupaten Banyuwangi. 2017. Kabupaten Banyuwangi dalam angka 2017. Banyuwangi, Badan Pusat Stastistik

Can, Cao, Wang Da-qing, Wang Hong-yan, Dai Lin. 2015. SWOT Analysis and Countermeasures of Ecological Agricultural Development of Jianshan Farm. Journal of Northeast Agricultural University (English Edition), Volume 22, Issue 1, Pages 12-21

David, F. R. 2010. Strategic Management. Sunardi, D., penerjemah; Wuriarti, P., editor. Jakarta: Salemba Empat. Terjemahan dari: Strategic Management. Ed ke-12.

Dinas Pertanian, Kehutanan dan Perkebunan. (2017). Laporan Tanaman Buah Buahan dan Sayuran Tahunan Tahun 2017. Badan Pusat Statistik dan Dinas Pertanian Kabupaten Banyuwangi.

Fauzi. 2016. Strategi Pengembangan Agribisnis Kentang Merah di Kabupaten Solok Sumatera Barat. Bogor: Institut Pertanian Bogor.

Journal of Northeast Agricultural University (English Edition), Volume 20, Issue 1, Pages 76-84

Kumar, V., et al. 2017. Marketing Channels, Marketing Cost, Margin and Producer's Share in Consumer's Rupee in Paddy Marketing. Agro Economist Journal. 4(1): 21-27.

Michailidis, Anastasios, Afroditi Papadaki-Klavdianou, Ioanna Apostolidou, Ignacio J. Lorite, Antonia Lorenzo Lopez. 2015. Exploring Treated Wastewater Issues Related to Agriculture in Europe, Employing a Quantitative SWOT Analysis. Procedia Economics and Finance, Volume 33, Pages 367-375

Peter Rauch, Ulrich J. Wolfsmayr, Stelian Alexandru Borz, Matevž Triplat, Maximilian Handlos. 2015. SWOT analysis and strategy development for forest fuel supply chains in South East Europe. Forest Policy and Economics, Volume 61, Pages 87-94

Sanela Arsić, Djordje Nikolić, Živan Živković. 2017. Hybrid SWOT - ANP - FANP model for prioritization strategies of sustainable development of ecotourism in National Park Djerdap, Serbia. Forest Policy and Economics, Volume 80, Pages 11-26

Tesfaw, A. H., and Alemu, D. 2013. Marketing channel and margin analysis: A case study of red pepper marketing at Jabitehinan District in Northwestern Ethiopia. Agricultura 1 Economics and Extension. 1(6): 031-040.

Wan-rong, Gu, Jin Yi, Meng Yao, Wang Jian-guo, Wei Shi. 2013. SWOT Analysis and Development Strategies of Maize Industry in Heilongjiang Province 